UDC 539.3 / 6

DOI 10.36910/6775-2313-5352-2020-17-22

Yu. Kholodnyak, Ph.D., A. Kostikov, Ph.D., S. Podlesny, Ph.D., S. Kaporovich, Ph.D.

Donbass State Engineering Academy

\title{
THE SOFTWARE ENHANCEMENT FOR SIMPLIFIED STRENGTH COMPUTATION OF
} I-BEAM

\begin{abstract}
The article is devoted to the subsequent development of previously created end-to-end computer programs for simplified strength analysis of statically determinable double-support and cantilevered I-beams. The aim of this development is to give these programs the additional functions to determine linear and angular displacements in beams by using the Mohr method. To this end, analytical dependencies have been established to determine the values of bending moments in the beam sections from the action of single force factors - the force and moment applied at arbitrary points of these beams. Based on these dependencies, an additional computation for determining displacements were made that improved the capacity of the existing programs for calculating beam strengths. The modified programs calculate the Mohr integrals, thereby determining the desired displacements and plotting their changes along the length of the beams. These programs have been successfully tested in a series of calculations of beams of various types and demonstrated its efficiency and effectiveness. The introduction of the modified programs in the educational process will provide students with new opportunities in the formation of their professional skills. The indicated programs will be useful for professional practitioners as a fairly simple calculation tool for solving real technical problems.
\end{abstract}

Keywords: I-beam, strength, displacements, simplified methodology, Mathcad, computer programs, calculation examples.

Introduction and statement of the problem. The rapid development of technology requires the preparation of highly educated engineering personnel to create new models of machines, mechanisms, materials, structures. To be successful latest achievements in science and technology have to fill the engineering training disciplines in higher education.

Strength of Material is key course for future engineers of almost all specialties, so the level of training engineers to solve complex technical task depends on course content compliance with up-to date knowledge.

Much attention in this course has traditionally been given to calculations on the strength and rigidity of core structures, especially beams, which are key elements of many machines and structures.

Beams have various forms of cross-sections, but the most common among them is the I-profile (Fig. 1), which combines significant economic advantages and ease of installation.

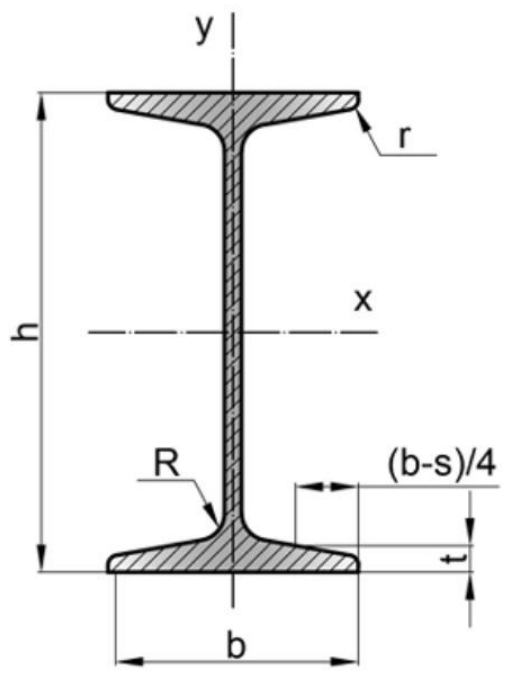

Figure 1 - I-beam ( GOST 8239-89) 
Strength calculations for statically defined I-beams usually consist of the following steps [1]:

- definition of support reactions (not required for cantilever beams);

- making diagram of transverse forces and bending moments;

- selection of the required I-beam size based on strength condition under normal stresses;

- check the selected I-beam size for the conditions of the strength at the tangent and equivalent stresses.

That procedure in the case of its implementation in the traditional ("manual") way requires considerable time and high enough skills of performers, which is its major drawback.

A certain improvement of this procedure is provided by the concept of the use of so-called safe factor spaces of I-beam, which formalizes and considerably simplifies the last two stages of calculation, while leaving the previous ones [2,3].

To maximize the benefits of this concept, cross-cutting applications have been created for strength calculations of statically defined double and cantilever I-beams [4, 5].

The aim of the work. The purpose of this work is to extend these programs by attaching calculation blocks to them to determine linear and angular displacements in beams.

Results of the work. Let's explain the essence of these movements. To do this, consider a beam with an arbitrary load, which does not lead to the appearance of plastic deformation in it (Fig. 2) As a result of this load, the beam loses its original straight shape and becomes convex. The longitudinal axis of the beam, which is called the elastic line, is bent and its points receive vertical linear displacements, which are usually denoted by the letter $\delta$. At the same time, the cross sections of the beam receive angular displacements - angles of rotation about horizontal axes passing through one or another point of the elastic line. Angular displacements are usually denoted by the letter $\Theta$. The indicated displacements are given by the indexes of the corresponding points.

a

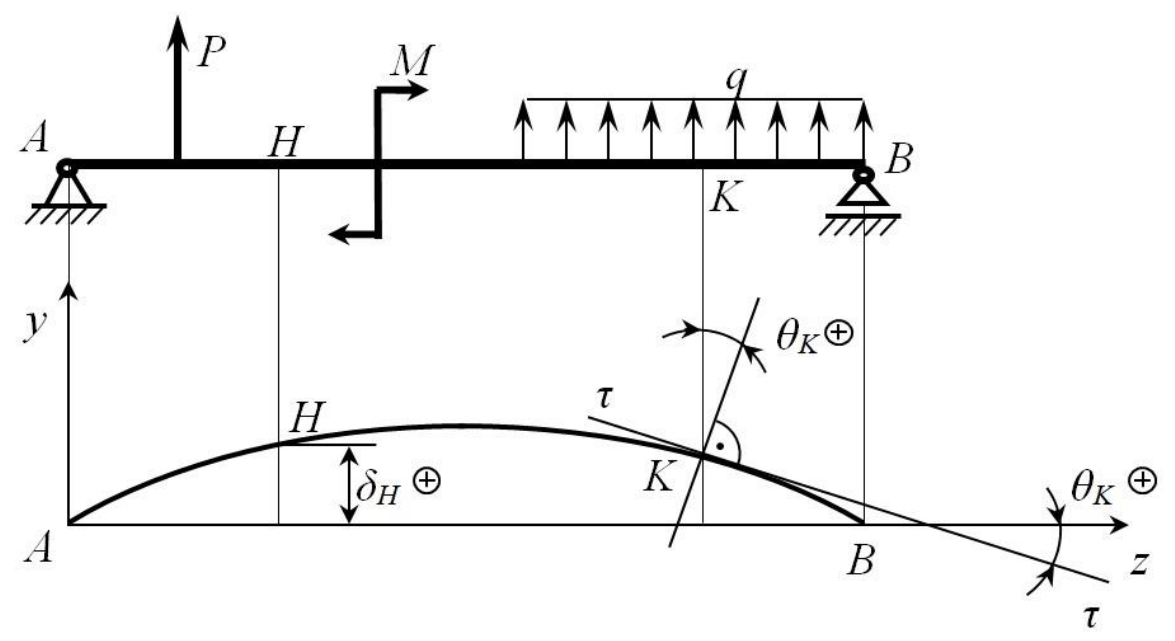

Figure $2-$ Scheme for the concepts of linear and angular displacements $a$ - loaded beam; $b$ - elastic line of the beam with marked displacements of points [6].

To determine the linear and angular displacements in beams, we use the universal Moor method

According to this method, to calculate the deflection of the beam at point $\mathrm{H}$ and the angle of rotation of the section passing through the point $K$ (hereinafter - section $K$ ), it is necessary to calculate the corresponding integrals:

$$
\begin{aligned}
\delta_{H} & =\frac{1}{E \cdot J_{x}} \cdot \int_{L} M(z) \cdot \bar{M}(z) \cdot d z, \\
\theta_{K} & =\frac{1}{E \cdot J_{x}} \cdot \int_{L} M(z) \cdot \bar{M}^{\prime}(z) \cdot d z,
\end{aligned}
$$

where $E \cdot J_{x}$ is the stiffness of the beam cross section when bending in the $y z$ plane (see Fig. 2);

$L$ is the length of the beam; 
$M(z)$ is the dependency of the bending moment from position $z$ on the beam for a given load;

$\bar{M}(z)$ is the dependency of the bending moment from position $z$ on the beam for the vertical unit force $P=1$, which is applied at point $H$;

$\bar{M}^{\prime}(z)$ is the dependency of the bending moment from position $z$ on the beam for a unit bending moment $M=1$, which is attached at cross-section $K$.

These dependencies are defined by above programs for calculating the strength of I-beams. The dependencies $\bar{M}(z)$ and $\bar{M}^{\prime}(z)$ from the positions of application of unit force factors to the beam are similarly defined in this paper.

Considering that the graphs of dependences $\bar{M}(z)$ (i.e. load plots of bending moments) in the calculations of the beams for strength were constructed on points with step $\Delta z$, we apply the same approach with respect to the dependences $\bar{M}(z)$ and $\bar{M}^{\prime}(z)$.

In this case, the calculation of the integrals (1) and (2) will be reduced to determine the corresponding sums (Fig. 3):

$$
\begin{aligned}
& \delta_{H}=\frac{1}{E \cdot J_{x}} \cdot \sum_{i=1}^{n} M_{i} \cdot \bar{M}_{i} \cdot \Delta z, \\
& \theta_{K}=\frac{1}{E \cdot J_{x}} \cdot \sum_{i=1}^{n} M_{i} \cdot \bar{M}_{i}^{\prime} \cdot \Delta z,
\end{aligned}
$$

where $i=1 \ldots n$ are the step numbers;

$n$ is the number of steps on the length of the beam;

$M_{i}, \bar{M}_{i}, \bar{M}_{i}^{\prime}$ are the current values of bending moments from a given load, unit force and unit torque.

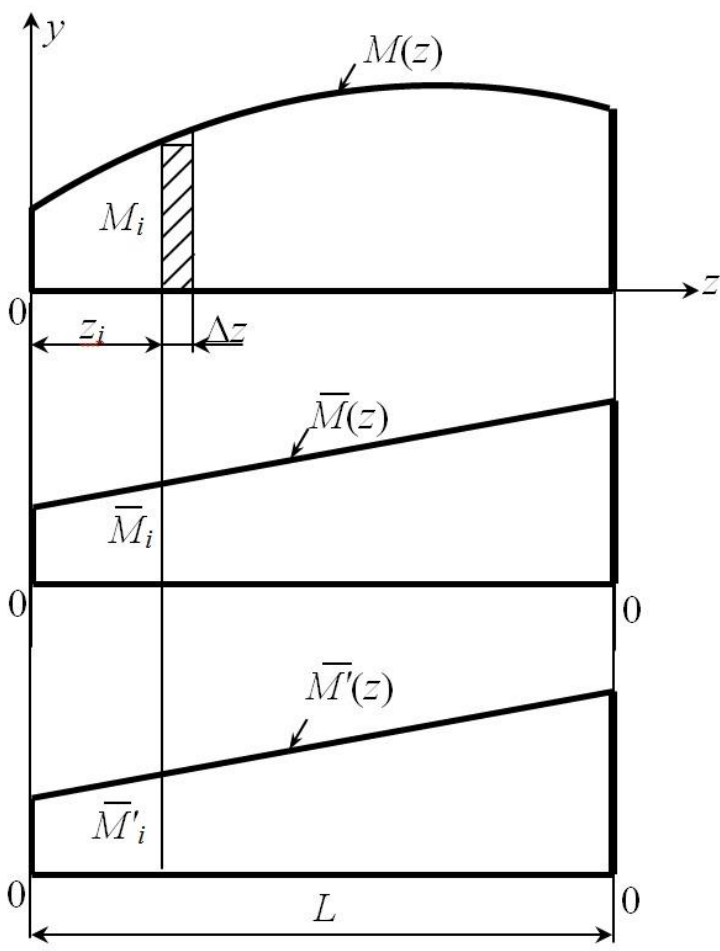

Figure 3 - Scheme for formulas (3) and (4)

Formulas (3) and (4) are approximate, but given the small size of the steps $(1 \ldots 2 \mathrm{~cm})$, they can be considered sufficiently accurate.

The definition of displacements is a logical extension of the previously created programs for calculating the strength of I-beams and attached to them in the form of an additional calculating block. 
In order to activate this block, it is necessary to enter into the existing programs the coordinates of the points at which the movements $-\ell_{H}$ and $\ell_{K}$ are defined.

Along with defining displacements at individual points of beams, enhanced programs also have the ability to build graphs of dependencies of $\delta_{H}(z)$ and $\theta_{K}(z)$ from distance along beam. To do this, enter the appropriate intervals $0 \leq \ell_{H} \leq L$ and $0 \leq \ell_{K} \leq L$.

The work of enhanced programs was investigated in a series of calculations of the different types steel beams Art.3 (Figs. 4 - 6). For these beams the problem of finding the corresponding Ibeam size was solved based on third strength theory with subsequent determination of linear and angular displacements in marked points and plotting the corresponding dependencies from distance along beam. In these calculations it is accepted: $[\sigma]=160 \mathrm{MPa}, E=2 \cdot 10^{5} \mathrm{MPa}$.

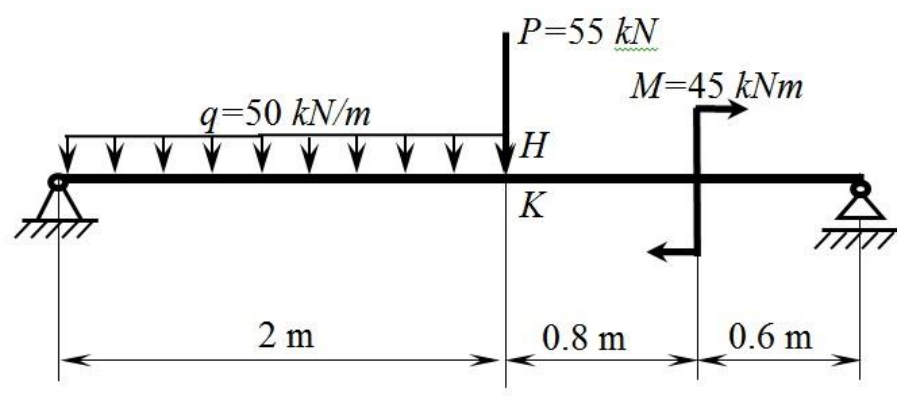

Figure 4 - Two-support beam plot

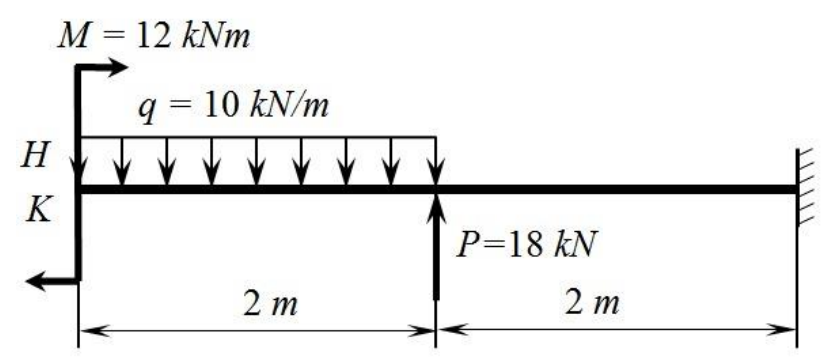

Figure 5 - The cantilever beam plot with right support

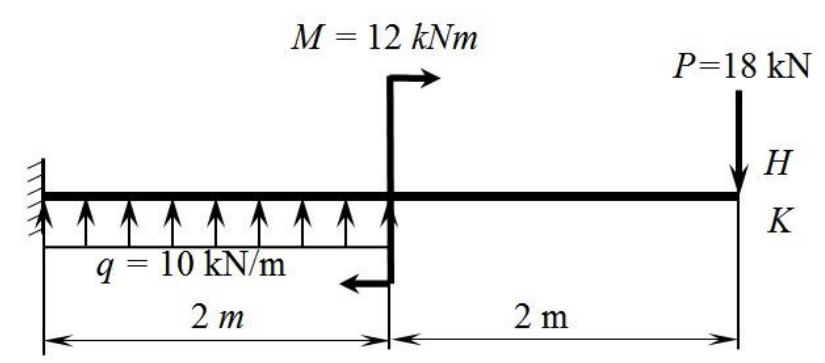

Figure 6 - The cantilever beam plot with left support

For computer calculations control, appropriate "manual" calculations were also performed using the traditional method of strength materials [1].

The results of both series of calculations are presented in Table 1. As an illustration of the completed development, a computer case of the two-support beam calculation is also illustrated (see Fig. 4).

The presented materials clearly indicate the workability and effectiveness of the enhanced programs. Compared to traditional methods of similar calculations, they significantly simplify and speed up the process of calculations, without reducing its accuracy 
Table 1

Comparative analysis of calculation results

\begin{tabular}{|l|c|c|c|c|c|c|}
\hline \multirow{2}{*}{ Meanings } & \multicolumn{3}{|c|}{ Computer Calculations results } & \multicolumn{3}{c|}{ Hand calculations results } \\
\cline { 2 - 7 } & Beam Fig.4 & Beam Fig.5 & Beam Fig.6 & Beam Fig.4 & Beam Fig.5 & Beam Fig.6 \\
\hline I-beam size & $27 \mathrm{a}$ & 14 & $27 \mathrm{a}$ & $27 \mathrm{a}$ & 14 & $27 \mathrm{a}$ \\
\hline$\delta_{\mathrm{H}}, \mathrm{mm}$ & $-5,986$ & $-50,000$ & $-37,200$ & $-5,989$ & $-50,117$ & $-37,213$ \\
\hline$\Theta_{\mathrm{K}}$, deg. & $-0,124$ & $-0,467$ & 0,808 & $-0,124$ & $-0,467$ & 0,806 \\
\hline
\end{tabular}

\section{COMPUTER VARIANT OF CALCULATION OF TWO-SUPPORT BEAM}

1. Input of concentrated forces, moments of couples and their location:

Enter the concentrated forces $P$, its position d, moments of couples $M$ and its positions $c$

$$
\mathrm{P}:=\left(\begin{array}{c}
-55 \\
0
\end{array}\right) \mathrm{kN} \quad \mathrm{d}:=\left(\begin{array}{l}
2 \\
0
\end{array}\right) \mathrm{m} \quad \mathrm{M}:=\left(\begin{array}{c}
45 \\
0
\end{array}\right) \mathrm{kN} \cdot \mathrm{m} \quad \mathrm{c}:=\left(\begin{array}{c}
2.8 \\
0
\end{array}\right) \mathrm{m}
$$
lengths:

2. Input of the length of beam, the support positions, the distributed loads, its positions and

Enter the distributed loads $q$, its positions $a$, its length $b$, the length of the beam $L$ and the support positions on the beam $\mathrm{I}_{1} \mathrm{Ta}_{2}$

$\mathrm{q}:=\left(\begin{array}{c}-50 \\ 0\end{array}\right) \frac{\mathrm{kN}}{\mathrm{m}} \quad \mathrm{a}:=\left(\begin{array}{l}0 \\ 0\end{array}\right) \mathrm{m} \quad \mathrm{b}:=\left(\begin{array}{l}2 \\ 0\end{array}\right) \mathrm{m} \quad \frac{\mathrm{L}}{\mathrm{m}}:=3.4 \mathrm{~m} \quad \frac{1}{\mathrm{M}}:=0 \mathrm{~m} \quad 1_{2}:=3.4 \mathrm{~m}$

3. Determination of the support reaction forces of the beam:

$$
\begin{aligned}
& R 2:=\frac{1}{\left(1_{2}-1_{1}\right)} \cdot\left[\sum_{i=1}^{\text {rowss }(M)} M_{i}-\sum_{i=1}^{\operatorname{rows}(P)}\left[P_{i} \cdot\left(d_{i}-1_{1}\right)\right]-\sum_{i=1}^{\operatorname{rows}(q)}\left[q_{i} \cdot b_{i} \cdot\left(a_{i}+\frac{b_{i}}{2}-1_{1}\right)\right]\right] \\
& R=7.5 \times 10^{4} \mathrm{~N} \\
& R:=\frac{1}{\left(1_{2}-1_{1}\right)} \cdot\left[-\sum_{i=1}^{\text {rowss }(M)} M_{i}+\sum_{i=1}^{\operatorname{rows}(P)}\left[P_{i} \cdot\left(d_{i}-1_{2}\right)\right]-\sum_{i=1}^{\operatorname{rows}(q)}\left[q_{i} \cdot b_{i} \cdot\left(l_{2}-a_{i}-\frac{b_{i}}{2}\right)\right]\right] \\
& R 1=8 \times 10^{4} \mathrm{~N}
\end{aligned}
$$

4. Plot of the shear force diagram:

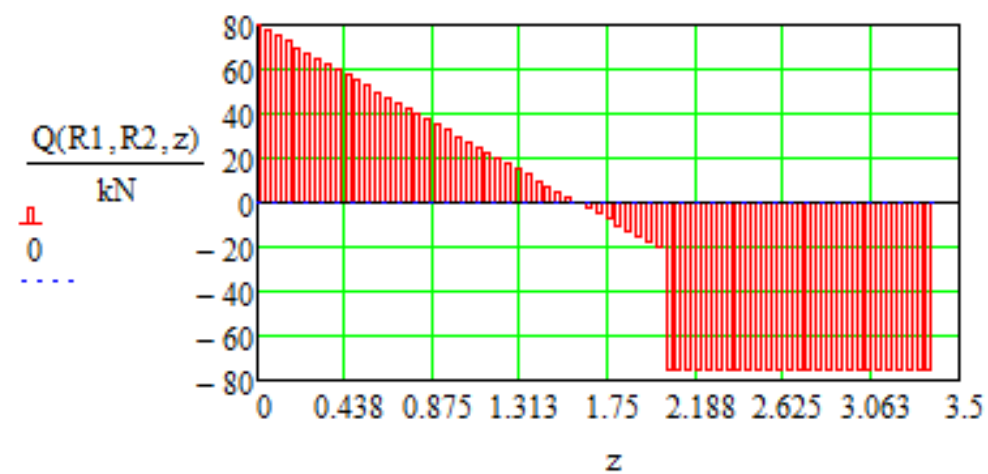

5. Plot of the bending moment diagram: 


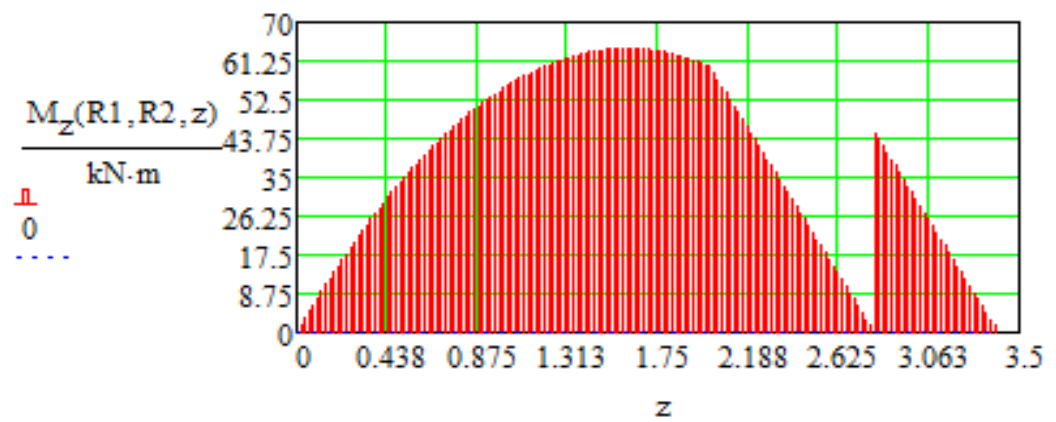

6. Determination of the I-beam size:

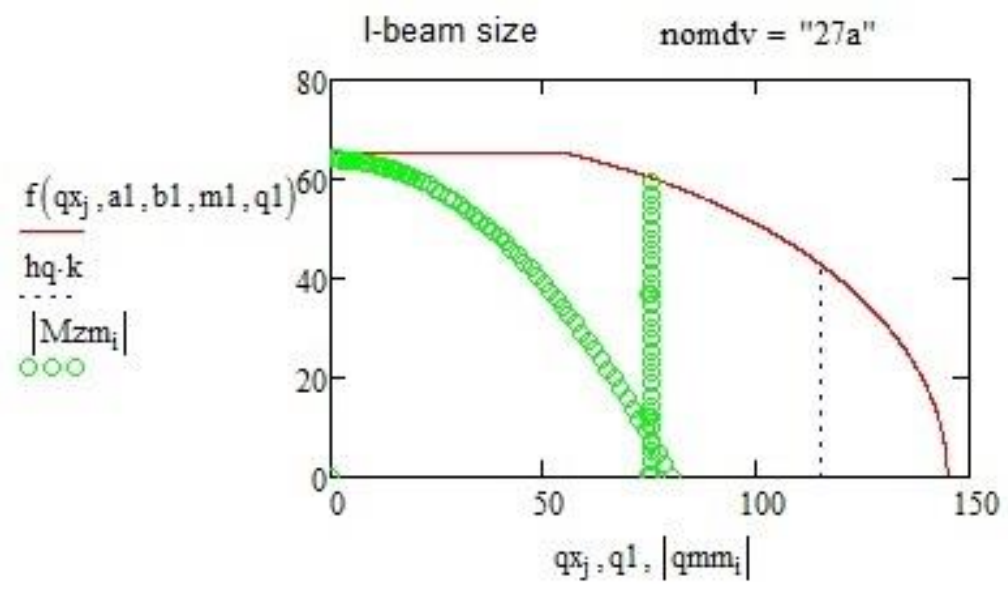

7. Comparision with the previous I-beam size:

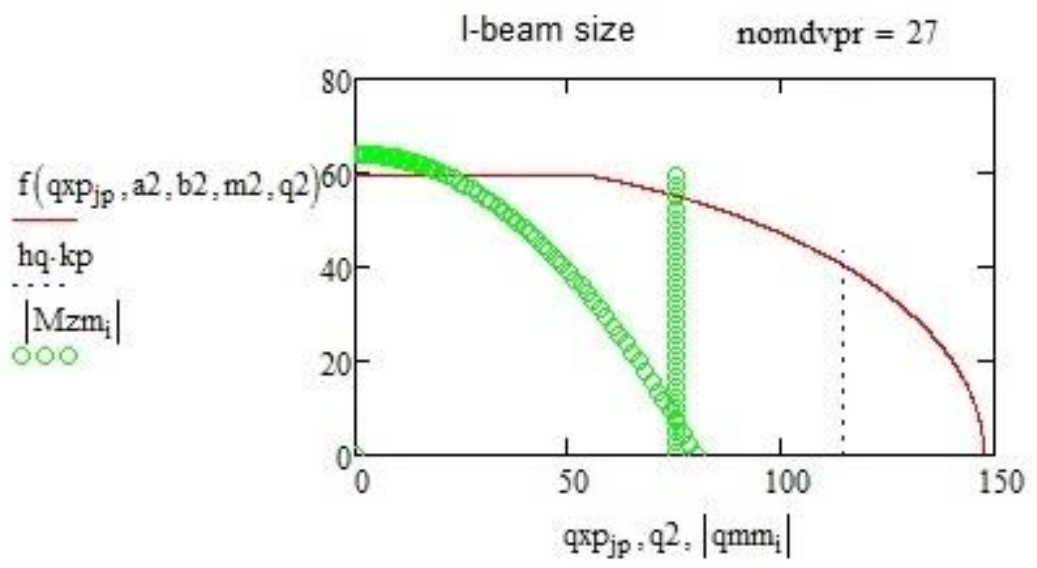

8. Dependencies of bending moment from position $\ell_{H}$ of unit force and coordinate $z$ of beam cross-section:

$$
\begin{aligned}
& \operatorname{MP1}\left(z, 1_{\mathrm{H}}\right):=\mid \begin{array}{l}
z-1_{\mathrm{H}} \text { if }\left(z>1_{\mathrm{H}}\right) \wedge\left(z \leq 1_{1}\right) \\
\left(z-1_{\mathrm{H}}\right)-\frac{\left(1_{2}-1_{\mathrm{H}}\right)}{\left(1_{2}-1_{1}\right)} \cdot\left(z-1_{1}\right) \text { if }\left(z>1_{1}\right) \wedge\left(z \leq 1_{2}\right) \\
0 \text { otherwise }
\end{array} \\
& \operatorname{MP2}\left(z, 1_{\mathrm{H}}\right):=\mid \begin{array}{l}
\frac{-\left(1_{2}-1_{H}\right)}{1_{2}-1_{1}} \cdot\left(z-1_{1}\right) \text { if }\left(z>1_{1}\right) \wedge\left(z \leq 1_{H}\right) \\
\frac{-\left(1_{2}-1_{H}\right)}{1_{2}-1_{1}} \cdot\left(z-1_{1}\right)+\left(z-1_{H}\right) \text { if }\left(z>1_{H}\right) \wedge\left(z \leq 1_{2}\right) \\
0 \text { otherwise }
\end{array} \\
& \operatorname{MP} 3\left(z, 1_{\mathrm{H}}\right):=\mid \begin{array}{l}
\frac{\left(1_{\mathrm{H}}-1_{2}\right)}{1_{2}-1_{1}} \cdot\left(z-1_{1}\right) \text { if }\left(z \geq 1_{1}\right) \wedge\left(z \leq 1_{2}\right) \\
1_{\mathrm{H}}-z \text { if }\left(z>1_{2}\right) \wedge\left(z \leq 1_{\mathrm{H}}\right) \\
0 \text { otherwise }
\end{array} \\
& \operatorname{MP}\left(z, 1_{H}\right):=\mid \begin{array}{l}
\operatorname{MP} 1\left(z, 1_{H}\right) \text { if }\left(1_{H} \geq 0\right) \wedge\left(1_{H} \leq 1_{1}\right) \\
\operatorname{MP} 2\left(z, 1_{H}\right) \text { if }\left(1_{H}>1_{1}\right) \wedge\left(1_{H} \leq 1_{2}\right) \\
\operatorname{MP} 3\left(z, 1_{H}\right) \text { if }\left(1_{H}>1_{2}\right) \wedge\left(1_{H} \leq L\right) \\
0 \text { otherwise }
\end{array}
\end{aligned}
$$

9. Construction of a plot of bending moments when the beam is loaded by unit force at point $H$ : 


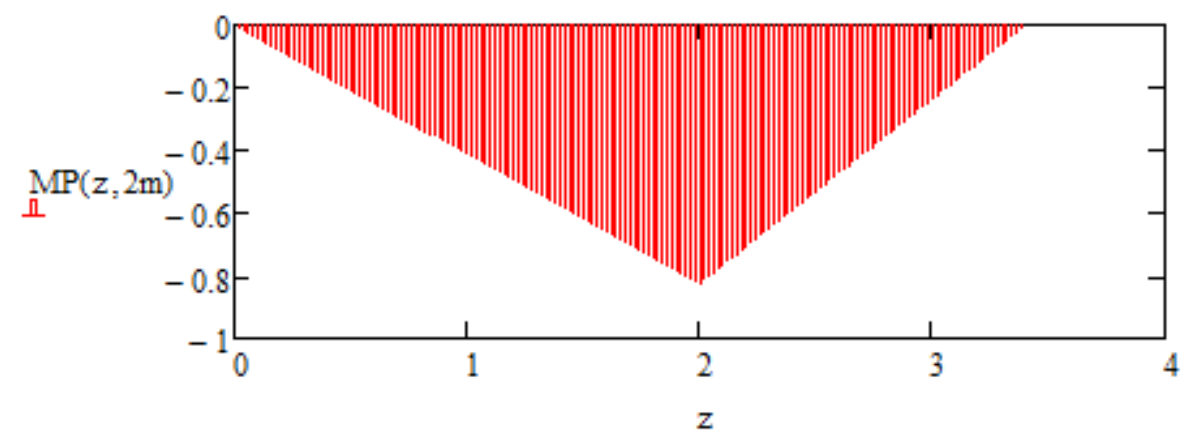

10. Finding the deflection $\delta_{H}$ at the given point of the beam:

$$
\begin{gathered}
\mathrm{E}:=2 \cdot 10^{11} \cdot \frac{\mathrm{N}}{\mathrm{m}^{2}} \quad \mathrm{Jx}:=5500 \cdot 10^{-8} \mathrm{~m}^{4} \\
\delta_{\mathrm{H}}\left({ }_{\mathrm{H}}\right):=\left(\int_{0}^{\mathrm{L}} \mathrm{MP}\left(\mathrm{z}, 1_{\mathrm{H}}\right) \cdot \mathrm{M}_{\mathrm{Z}}(\mathrm{R} 1, \mathrm{R} 2, \mathrm{z}) \mathrm{dz}\right) \cdot \mathrm{Kff} \quad \delta_{\mathrm{H}}(2 \mathrm{~m})=-5.98562037 \times 10^{-3} \mathrm{~m}
\end{gathered}
$$

11. Constructing a graph of change $\delta_{H}$ from distance along the beam:

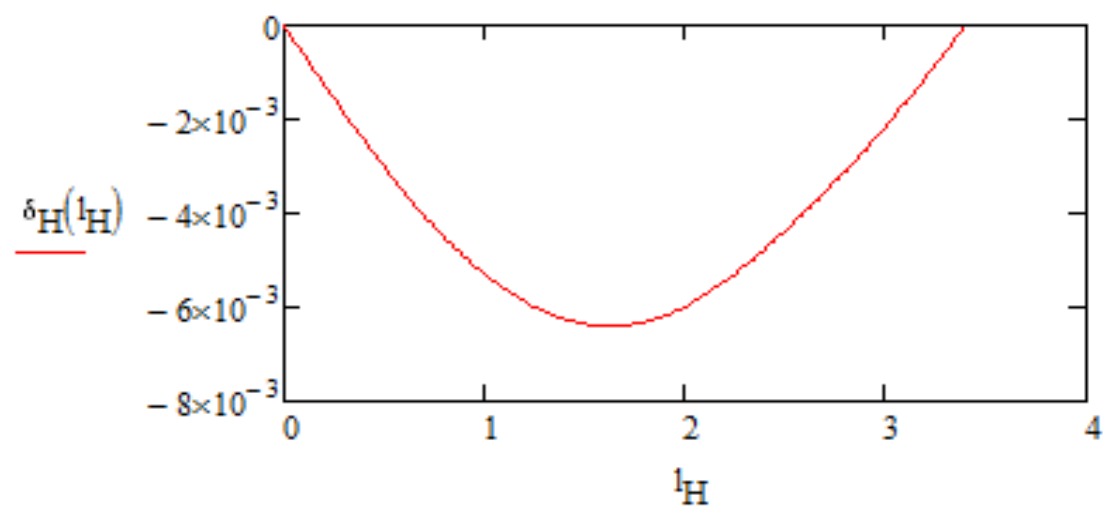

12. Dependences of the bending moment on the coordinate of the cross section of the beam $z$ and the position of a unit moment $\ell_{k}$ :

$$
\begin{aligned}
& \operatorname{MPP} 1\left(z, 1_{\mathrm{k}}\right):=\left|\begin{array}{l}
1 \text { if }\left(z>1_{\mathrm{k}}\right) \wedge\left(z \leq 1_{1}\right) \\
1-\frac{1}{1_{2}-1_{1}} \cdot\left(z-1_{1}\right) \text { if }\left(z>1_{1}\right) \wedge\left(z \leq 1_{2}\right) \\
0 \text { otherwise }
\end{array} \quad \operatorname{MPP2}\left(z, 1_{\mathrm{k}}\right):=\right| \begin{array}{l}
\frac{-1}{1_{2}-1_{1}} \cdot\left(z-1_{1}\right) \text { if }\left(z>1_{1}\right) \wedge\left(z \leq 1_{\mathrm{k}}\right) \\
\frac{-1}{1_{2}-1_{1}} \cdot\left(z-1_{1}\right)+1 \text { if }\left(z>1_{\mathrm{k}}\right) \wedge\left(z \leq 1_{2}\right) \\
0 \text { otherwise }
\end{array} \\
& \operatorname{MPP} 3\left(z, 1_{\mathrm{H}}\right):=\left|\begin{array}{l}
\frac{-1}{1_{2}-1_{1}} \cdot\left(z-1_{1}\right) \text { if }\left(z \geq 1_{1}\right) \wedge\left(z \leq 1_{2}\right) \\
-1 \text { if }\left(z>1_{2}\right) \wedge\left(z \leq 1_{\mathrm{H}}\right) \\
0 \text { otherwise }
\end{array} \quad \operatorname{MPP}\left(z, 1_{\mathrm{H}}\right):=\right| \begin{array}{l}
\operatorname{MPP} 1\left(z, 1_{\mathrm{H}}\right) \text { if }\left(1_{\mathrm{H}} \geq 0\right) \wedge\left(1_{\mathrm{H}} \leq 1_{1}\right) \\
\operatorname{MPP} 2\left(z, 1_{\mathrm{H}}\right) \text { if }\left(1_{\mathrm{H}}>1_{1}\right) \wedge\left(1_{\mathrm{H}} \leq 1_{2}\right) \\
\operatorname{MPP} 3\left(z, 1_{\mathrm{H}}\right) \text { if }\left(1_{\mathrm{H}}>1_{2}\right) \wedge\left(1_{\mathrm{H}} \leq \mathrm{L}\right) \\
0 \text { otherwise }
\end{array}
\end{aligned}
$$

$K:$

13. Creation of the bending moments diagram when the beam is loaded by unit moment at point 


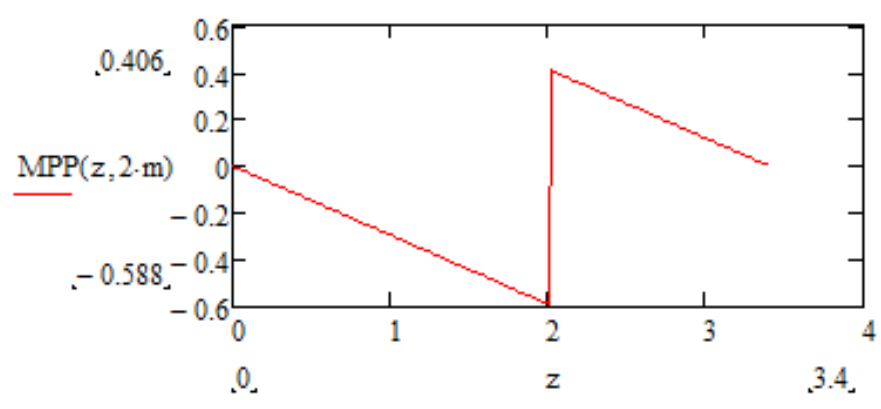

14. Finding the angle of rotation of the cross-section $\theta_{k}$ at a given point of the beam:

$$
\theta_{\mathrm{k}}\left(\mathrm{l}_{\mathrm{k}}\right):=\frac{1}{\mathrm{E} \cdot \mathrm{Jx}} \cdot \int_{0}^{\mathrm{L}} \operatorname{MPP}\left(z, \mathrm{l}_{\mathrm{k}}\right) \cdot \mathrm{M}_{\mathrm{z}}(\mathrm{R} 1, \mathrm{R} 2, \mathrm{z}) \mathrm{d} z \quad \theta_{\mathrm{k}}(2 \cdot \mathrm{m})=-2.164 \times 10^{-3}
$$

15. Plot of the graph of change $\theta_{k}$ from distance along the beam:

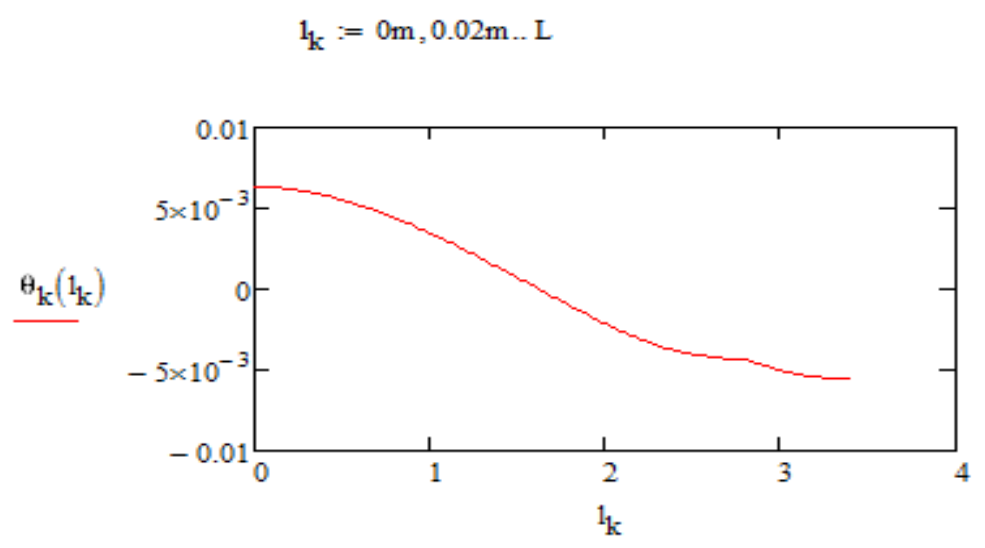

Conclusions. An additional calculation module has been developed for previously created endto-end computer programs for simplified calculation of the strength of statically defined two-support and cantilever beams.

The developed module allows to determine the linear and angular displacements at given points of beams by the Moore method and to plot their graphs.

Enhanced by this module, these existing programs have been successfully tested in a series of calculations of beams of different types, demonstrating their workability and effectiveness. Compared to similar "manual" calculations, they significantly simplify and shorten the calculation process over time, without reducing its accuracy.

The implementation of enhanced software in the educational process will give students new opportunities to develop their professional skills. The mentioned programs as a simple enough calculation tool will also be useful for practitioners in solving their real technical problems.

The work in this area cannot be considered as complete. The challenges of combining both enhanced programs and increasing the variety of beam profiles (i.e, cross-sectional configurations) that are appropriate for them remain relevant.

\section{References}

1. Збірник розрахунково-графічних завдань 3 курсу «Опір матеріалів»: навчальний посібник / Л. В. Кутовий [та ін.]. - Краматорськ: ДДМА 2007. - 220 с.

2. Холодняк Ю.С. О методике изложения вопросов прочности двутавровой балки / Ю.С. Холодняк, А.В. Периг, И.А. Матвеев // Современное образование и интеграционные процессы: сб. науч. раб. - Краматорск, ДГМА, 2012. - С. $351-362$.

3. Холодняк Ю.С. Совершенствование методики прочностного расчёта двутавровой балки и её изложения в курсах технических дисциплин / Ю.С. Холодняк, А.В. Периг, И.А. Матвеев // Вестник Пермского национального исследовательского политехнического университета. - Пермь: ПНИПУ, 2012. - С. 77 - 90. 
4. Про комп'ютерні програми до спрощеної методики комплексної оцінки міцності двотаврових балок / Ю.С. Холодняк [та ін.] // Вісник Донбаської державної машинобудівної академії: зб. наук. пр...- Краматорськ: ДДМА, 2019. - № 3 (47).- С. 72 - 81.

5. About computer programs for simplified methodology of complex assessment of strength of two - beam beams / Yu.S. Holodnyak [et al.] // Перспективні технології та прилади: зб. наук. пр.. Луцьк: НТУ, 2019. - №15. - С.99- 108.

6. Писаренко Г. С. Опір матеріалів / Г. С. Писаренко, О. Л. Квітка, Є. С. Уманський. - К.: Вища школа, 2004. - 655 с.

Холодняк Ю.С., Костіков О.А., Подлєсний С.В., Капорович С.В.

Донбаська державна машинобудівна академія

\section{РОЗШИРЕННЯ ФУНКЦІОНАЛЬНИХ МОЖЛИВОСТЕЙ ПРОГРАМНОГО ЗАБЕЗПЕЧЕННЯ ДЛЯ СПРОЩЕНОГО РОЗРАХУНКУ НА МІЦНІСТЬ ДВОТАВРОВИХ БАЛОК}

Стаття присвячена розробиі додаткового розрахункового блоку до раніше створених наскрізних комп'ютерних програм спрощеного розрахунку на міџність статично визначуваних двохопорних $і$ консольних двотаврових балок. Метою даної розробки є надання вказаним програмам додаткових функиій визначення лінійних $і$ кутових переміщень в балках за методом Мора. 3 иією метою встановлені аналітичні залежності для визначення величин згинальних моментів у перерізах балок від дії одиничних силових факторів - сили і моменту, прикладених у довільних точках ичх балок. На основі иих залежностей був створений додатковий розрахунковий блок з визначення переміщень, який подовжив існуючі програми розрахунків балок на міџність. Подовжені програми обчислюють інтеграли Мора, тим самим визначаючи шукані переміщення $і$ будуючи графіки їх зміни по довжині балок. Ці програми пройшли успішну апробацію в серії розрахунків балок різних типів, продемонструвавши свою працездатність і ефективність. Впровадження подовжених програм у навчальний процес надасть студентам нові можливості в формуванні у них професійних навичок. Вказані програми як достатньо простий розрахунковий засіб будуть корисними також і для фахівиів - практиків при розв 'язанні ними реальних технічних задач.

Ключові слова: двотаврові балки, міщність, переміщення, спрощені розрахунки, Mathcad, комп'ютерні програми.

Холодняк Ю.С., Костиков А.А., Подлесный С.В., Капорович С.В.

Донбасская государственная машиностроительная академия

\section{РАСШИРЕНИЕ ФУНКЦИОНАЛЬНЫХ ВОЗМОЖНОСТЕЙ ПРОГРАММНОГО ОБЕСПЕЧЕНИЯ ДЛЯ УПРОЩЁННОГО РАСЧЁТА НА ПРОЧНОСТЬ ДВУТАВРОВЫХ БАЛОК}

Статья посвящена разработке дополнительного расчётного блока к ранее созданным сквозным компьютерным программам упрощённого расчёта на прочность статически определимых двухопорных и консольных двутавровых балок. Целью данной разработки является придание указанным программам дополнительных функичий определения линейных и угловых перемещений в балках по методу Мора. С этой целью установлены аналитические зависимости для определения величин изгибающих моментов в сечениях балок от действия единичных силовых факторов - силь и момента, приложенных в произвольных точках этих балок. На основе этих зависимостей был создан дополнительный расчётный блок по определению перемещений, удлинивщий существующие программы расчётов балок на прочность. Удлинённые программы вычисляют интегралы Мора, тем самым определяя искомые перемещения и строя графики их изменения по длине балок. Эти программы прошли успешную апробаиию в серии расчётов балок различных типов, продемонстрировав свою работоспособность и эффективность. Внедрение удлинённых программ в учебный процесс предоставит студентам новые возможности в формировании у них профессиональных навыков. Указанные программы как достаточно простое расчётное средство будут полезными и для специалистов - практиков при решении ими реальных технических задач.

Ключевые слова: двутавровые балки, прочность, перемещения, упрощённые расчёты, Mathcad, компьютерные программы

() Yu. Kholodnyak, A. Kostikov, S. Podlesny, S. Kaporovich 